\title{
A INSTITUIÇÃO DO PET-ANTROPOLOGIA NA UFCG E O FORTALECIMENTO DA PRESENÇA FEMININA NA ANTROPOLOGIA NO NORDESTE BRASILEIRO
}

\author{
Elizabeth Christina de Andrade Lima ${ }^{1}$ \\ https://orcid.org/0000-0003-3072-3624 \\ Márcio Caniello ${ }^{2}$ \\ https://orcid.org/0000-0003-2765-9393 \\ Vanderlan Silva ${ }^{3}$ \\ https://orcid.org/0000-0003-4299-0711
}

\begin{abstract}
RESUMO
O artigo apresenta a implantação do Programa de Educação Tutorial (PET) Antropologia na Universidade Federal da Paraíba, campus II, transformada em 2002 na Universidade Federal de Campina Grande. Analisa, ainda, os impactos do Programa nas trajetórias acadêmicas das estudantes bolsistas, com destaque para o empoderamento feminino no cotidiano do PET Antropologia e na Graduação em Ciências Sociais, desde sua implantação, no ano de 1988, até os dias atuais. Na primeira parte do artigo, discutimos o processo de implantação, as bases filosóficas e as metodologias de trabalho do Programa. Na sequência, são analisadas as transformações implantadas pelo Ministério da Educação, que mudaram não apenas o significado da sigla PET, até então Programa Especial de Treinamento, passando a ser designado Programa de Educação Tutorial, bem como as bases filosóficas originais do programa e suas metodologias de trabalho. $\mathrm{O}$ texto foi elaborado a partir de pesquisas documentais em arquivos da UFCG, do PET Antropologia e dos arquivos pessoais dos autores. Realizamos ainda dez entrevistas com mulheres que participaram do programa em vários momentos de sua história, de modo online, através do programa de troca de mensagens da rede social WhatsApp, cujas respostas foram disponibilizadas de forma escrita e oral. Nos resultados e conclusões, demonstramos que o PET Antropologia tem gerado impactos positivos na vida acadêmica e profissional dos alunos bolsistas e empoderado o gênero feminino, cujas consequências podem ser sentidas na antropologia do Nordeste e do Brasil, mediante a atuação de muitos profissionais cujas origens acadêmicas remontam ao PET Antropologia.
\end{abstract}

Palavras-chave: PET Antropologia, Empoderamento Feminino, Nordeste.

\section{THE INSTITUTION OF PET-ANTHROPOLOGY IN UFCG AND THE STRENGTHENING OF THE FEMALE PRESENCE IN ANTHROPOLOGY IN NORTHEAST BRAZIL}

\begin{abstract}
The article presents the implementation of the Tutorial Education Program (PET) Anthropology at the Federal University of Paraíba, campus II, transformed in 2002 into the Federal University of Campina Grande. It also analyzes the impacts of the Program on the academic trajectories of scholarship students, with emphasis on female empowerment in the daily life of PET Anthropology and in the Graduation in Social Sciences, since its implementation in 1988 up to the present day. The first part of the article discusses the implementation process, the philosophical bases and the work methodologies of the Program. Then, the transformations implemented by the Ministry of Education

\footnotetext{
1 Doutora em Sociologia pela UFC. Professora Titular de Antropologia da UFCG e do PPGCS. E-mail: ecalima@terra.com.br.

2 Doutor em Sociologia pela UFPE. Professor Titular de Antropologia da UFCG e do PPGCS. E-mail: marciocaniello@gmail.com.

${ }^{3}$ Doutor em Ciências Sociais pela Paris V (Sorbonne). Professor Associado de Antropologia da UFCG e do PPGCS. Email: vanderlansilva@uol.com.br.
} 
are analyzed, which changed not only the meaning of the acronym PET, until then the Special Training Program, becoming known as the Tutorial Education Program, as well as the original philosophical bases of the program and its methodologies of job. The text was prepared based on documentary research in the archives of UFCG, PET Anthropology and in the personal files of the authors. We also conducted ten interviews with women who participated in the program at several times in its history, online, through the messaging program of the social network WhatsApp, whose responses were made available in written and oral form. In the results and conclusions we demonstrate that PET Anthropology has generated positive impacts on the academic and professional life of scholarship students and empowered the female gender, whose consequences can be felt in the anthropology of the northeast and Brazil, through the performance of many professionals whose academic origins go back at PET Anthropology.

Keywords: PET Anthropology, Women's Empowerment, Northeast.

\section{LA INSTITUCIÓN DE ANTROPOLOGÍA PET EN UFCG Y EL FORTALECIMIENTO DE LA PRESENCIA FEMENINA EN ANTROPOLOGÍA EN EL NORESTE DE BRASIL}

\section{RESUMEN}

El artículo presenta la implementación del Programa de Educación Tutorial (PET) Antropología en la Universidad Federal de Paraíba, campus II, transformado en 2002 en la Universidad Federal de Campina Grande. También analiza los impactos del Programa en las trayectorias académicas de los estudiantes becados, con énfasis en el empoderamiento femenino en la vida cotidiana de la PET Antropología y en la Graduación en Ciencias Sociales, desde su implementación en 1988 hasta la actualidad. La primera parte del artículo analiza el proceso de implementación, las bases filosóficas y las metodologías de trabajo del Programa. Luego, se analizan las transformaciones implementadas por el Ministerio de Educación, que cambiaron no solo el significado de la sigla PET, hasta entonces Programa de Capacitación Especial, pasando a denominarse Programa de Educación Tutorial, así como las bases filosóficas originales del programa y sus metodologías de trabajo. El texto fue elaborado a partir de la investigación documental en los archivos de UFCG, PET Antropología y en los archivos personales de los autores. También realizamos diez entrevistas a mujeres que participaron del programa en distintos momentos de su historia, en línea, a través del programa de intercambio de mensajes de la red social Whatsapp, cuyas respuestas se pusieron a disposición en forma escrita y oral. En los resultados y conclusiones demostramos que PET Antropología ha generado impactos positivos en la vida académica y profesional de los becarios y empoderamiento del género femenino, cuyas consecuencias se pueden sentir en la antropología del Nordeste y Brasil, a través del desempeño de muchos profesionales cuyos orígenes académicos se remontan PET Antropología.

Palabras clave: PET Antropología, Empoderamiento Femenino, Noreste.

\section{INTRODUÇÃO}

Não há como abordar o desenvolvimento da Antropologia no Nordeste brasileiro sem fazer menção ao Programa de Educação Tutorial em Antropologia (PET-Antropologia), dirigido a alunos de graduação, que serviu e continua a servir como um ambiente de formação de quadros acadêmicos qualificados para ocupar a prática docente, contribuindo para o amadurecimento dessa área do conhecimento em nossa região. 
Este artigo tem por objetivo historiar a instituição do PET-Antropologia na Universidade Federal de Campina Grande desde a sua concepção até os dias atuais, com destaque para as suas várias fases de existência, ressaltando a contribuição do programa para a formação discente e docente do Curso de Ciências Sociais, em suas duas habilitações: Bacharelado e Licenciatura.

Intenta, ainda, destacar o papel do PET-Antropologia como um programa que propicia não só a convivência acadêmica, a camaradagem entre os seus pares, mas, sobretudo, refletir até que ponto esta experiência coletiva promove o questionamento e mudanças sobre as relações e construções de gênero, permitindo, por meio da reflexão e das práticas vivenciadas no dia a dia, repensar os "lugares" de gênero masculino e feminino.

Procuraremos demonstrar, enfim, que, considerando a maneira como se institui do ponto de vista teórico e prático, o PET-Antropologia foi e continua sendo instrumento de empoderamento feminino, além de proporcionar a formação de um quadro de jovens antropólogos e antropólogas atuantes no contexto regional, os quais têm contribuído para o fortalecimento da Antropologia no Nordeste.

Para tanto, realizamos entrevistas com dez egressas do PET-Antropologia, de diferentes fases de ingresso no Programa, e lhes perguntamos sobre suas experiências junto ao programa, a convivência coletiva e embates vividos a partir da construção e relações de gênero, e como elas se pensam e se veem antes e depois do PET. Optamos pelo uso de pseudônimos para preservar as identidades das respondentes.

$\mathrm{O}$ artigo está dividido em três partes: primeiramente, descrevemos a história do PET como um programa tutorial e como surgiu o PET-Antropologia na UFCG; em seguida, apresentamos as mudanças ocorridas nos programas PET no Brasil e como elas impactaram o programa na UFCG; finalmente, analisamos as narrativas das petianas entrevistadas, que trazem para o centro do debate a questão de gênero e de como elas se constituíram, enquanto mulheres, dentro e fora do Programa, antes e depois do PET.

\section{HISTÓRICO E CARACTERÍSTICAS DO PROGRAMA PET-ANTROPOLOGIA}

O Programa Especial de Treinamento, primeiro termo designado à sigla PET, é formado por alunos que demonstram potencial, interesse e habilidades destacadas em cursos de graduação reconhecidos pelo Conselho Nacional de Educação ou por outro órgão através da sua determinação. O apoio é concedido ao curso de graduação, por período indeterminado, e ao bolsista até a conclusão da sua graduação. Criado em 1979, ele foi aperfeiçoado e ampliado durante vinte anos sob o acompanhamento e avaliação da CAPES (Coordenação de Aperfeiçoamento de Pessoal de Nível Superior) e da SESU (Secretaria de Ensino Superior do Ministério da Educação - MEC), que passou a responder exclusivamente pelo programa a partir do ano 2003. 
O PET busca propiciar aos alunos, sob a orientação de um professor tutor, condições para a realização de atividades extracurriculares que complementam a sua formação acadêmica, procurando atender mais plenamente às necessidades do próprio curso de graduação e ampliar e aprofundar os objetivos e conteúdos programáticos que integram sua grade curricular. Neste sentido, o programa busca proporcionar uma melhoria da qualidade acadêmica dos cursos de graduação onde é desenvolvido, constituindo-se, portanto, uma modalidade de investimento acadêmico com sérios compromissos pedagógicos, éticos e sociais.

Orientado pelo objetivo de formar globalmente o aluno, o PET não visa apenas proporcionar aos bolsistas uma nova e diversificada gama de conhecimento acadêmico, mas assume a responsabilidade de contribuir para sua melhor qualificação como pessoa humana e como membro da sociedade.

O Grupo Especial de Treinamento em Antropologia - PET Antropologia - foi criado no ano de 1988 e está vinculado ao Curso de Graduação em Ciências Sociais e, à época, ao Departamento de Sociologia e Antropologia, hoje, Unidade Acadêmica de Ciências Sociais do Centro de Humanidades da, hoje, Universidade Federal de Campina Grande, antes, Universidade Federal da Paraíba.

O Programa PET-Antropologia da UFCG é referência nos estudos de Antropologia, não só por sua qualidade acadêmica, mas porque é o único Programa que busca realizar estudos nessa área do conhecimento, não só no Nordeste brasileiro, mas em todo o Brasil. Daí o seu ineditismo: ser o único programa que objetiva formar o graduando no aprofundamento dos estudos e investigação antropológicas.

A ideia da criação do PET-Antropologia na UFPB, atualmente UFCG, partiu da iniciativa do professor do então Departamento de Sociologia e Antropologia, Márcio de Mattos Caniello. O professor Márcio certa vez narrou que, no ano de 1987, tomou conhecimento do Programa PET/CAPES/SESU por meio de um Edital afixado em uma das paredes do Hall das Placas, no Centro de Humanidades da UFPB; aquilo o chamou atenção e de pronto veio o intento em concorrer ao Edital, sugerindo, por meio de um Projeto e de um Plano de Ações, a proposta de criação de um PET em Antropologia.

O Projeto foi enviado à Brasília e assinado pelos professores Márcio Caniello e Josefa Salete, e algum tempo depois chegou a feliz notícia de sua aprovação. O PET sempre foi uma espécie de "menina dos olhos" da área de Antropologia e teve, de maneira inquestionável, sempre o apoio da área, por meio da presença efetiva de todos os professores a ela vinculados, seja orientando a Monografia Semestral dos bolsistas, seja desempenhando a tutoria.

Em seu primeiro ano de existência, o programa PET-Antropologia foi tutorado pelo professor Márcio de Mattos Caniello, em 1988. No período de 1989 a 1991, o PET foi tutorado pela professora Josefa Salete Cavalcanti e, de 1992 a 1995, a professora Elizabeth Christina de Andrade Lima 
assumiu a tutoria. Entre 1996 e 1999 o programa foi tutorado pela professora Mércia Rejane Batista. No ano 2000, o professor Rogério Humberto Zeferino assume tal responsabilidade e, entre 2001 e 2007, a tutoria foi novamente exercida pela professora Elizabeth Christina de Andrade Lima. A partir de 2008, a professora Mércia Rejane volta a ser tutora, permanecendo até meados do segundo semestre de 2014. De 2014 até o momento, o PET está sendo tutorado pelo professor Vanderlan Francisco da Silva. Desde o seu início, o Programa foi tutorado por seis professores, três homens e três mulheres.

Na primeira fase, o Programa PET era formado por um máximo de doze alunos do Curso de Ciências Sociais, selecionados mediante um rigoroso processo. Para tanto, esses alunos recebem uma bolsa mensal e têm a oportunidade de permanecer no programa até o término de seu curso, de acordo com o seu desempenho e participação.

Ao ingressar no PET-Antropologia, o aluno tem a oportunidade de aprofundar os estudos dos principais paradigmas das Ciências Sociais, em especial da Antropologia, além de discutir, na íntegra, a obra de autores clássicos. O grupo assim formado, um misto de alunos veteranos e ingressantes, coordenado por um professor tutor e por uma equipe de apoio, desenvolve atividades, cujo planejamento se faz nas reuniões semanais. As atividades são organizadas no início de cada ano, de acordo com os objetivos gerais do programa. Dentre as atividades desenvolvidas, merecem destaque: produção monográfica; treinamento em informática; seminários semanais e comunicações escritas; estudo de línguas estrangeiras; trabalhos de pesquisa coletiva; atividades de extensão, tais como: visitas culturais e participação em eventos científicos regionais e nacionais. Uma dessas visitas culturais está ilustrada nas fotografias abaixo, momento no qual os petianos pioneiros, com sua tutora Josefa Salete, fizeram visitas à UFPB e à Fundação Casa José de Américo, na cidade de João Pessoa.

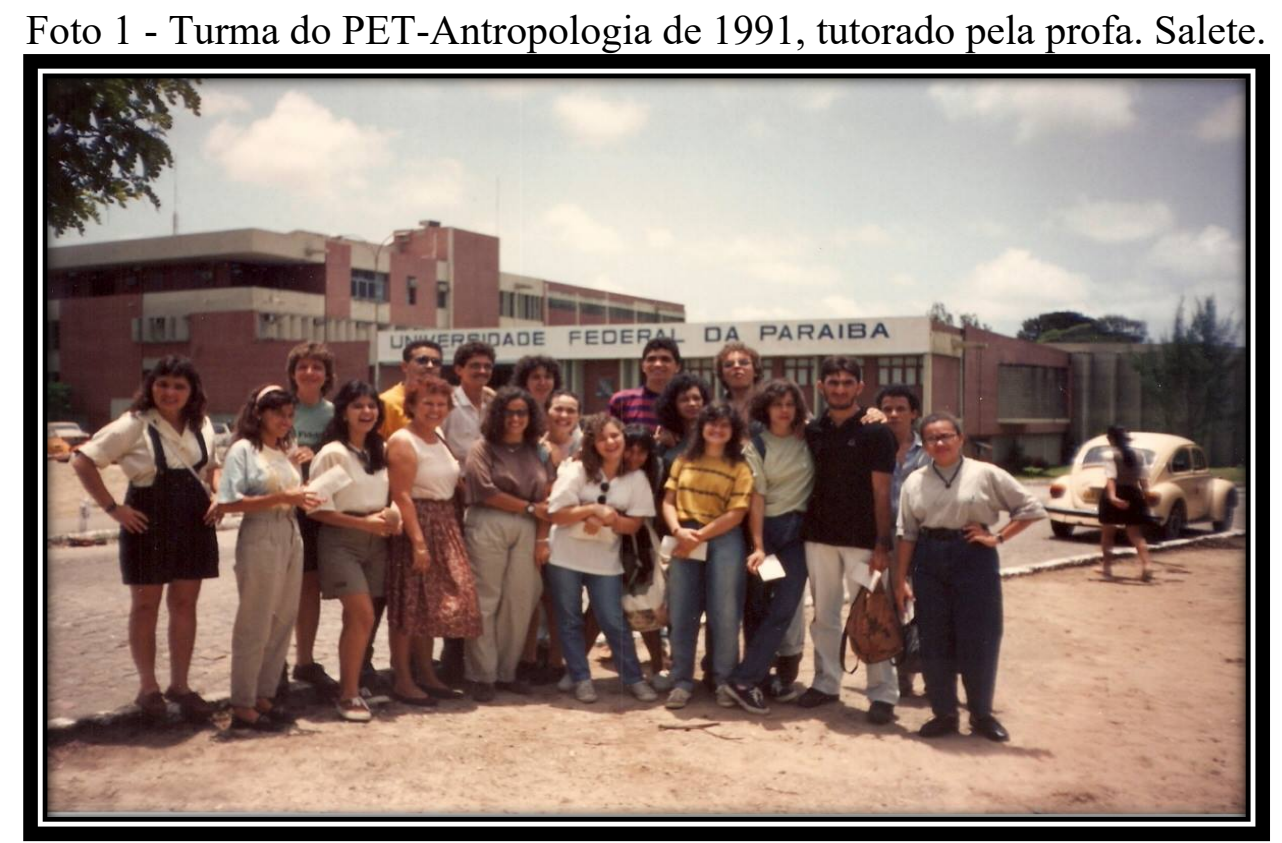

Fonte: Arquivo PET Antropologia 
Foto 2 - Turma do PET-Antropologia de 1991, tutorado pela profa. Salete.

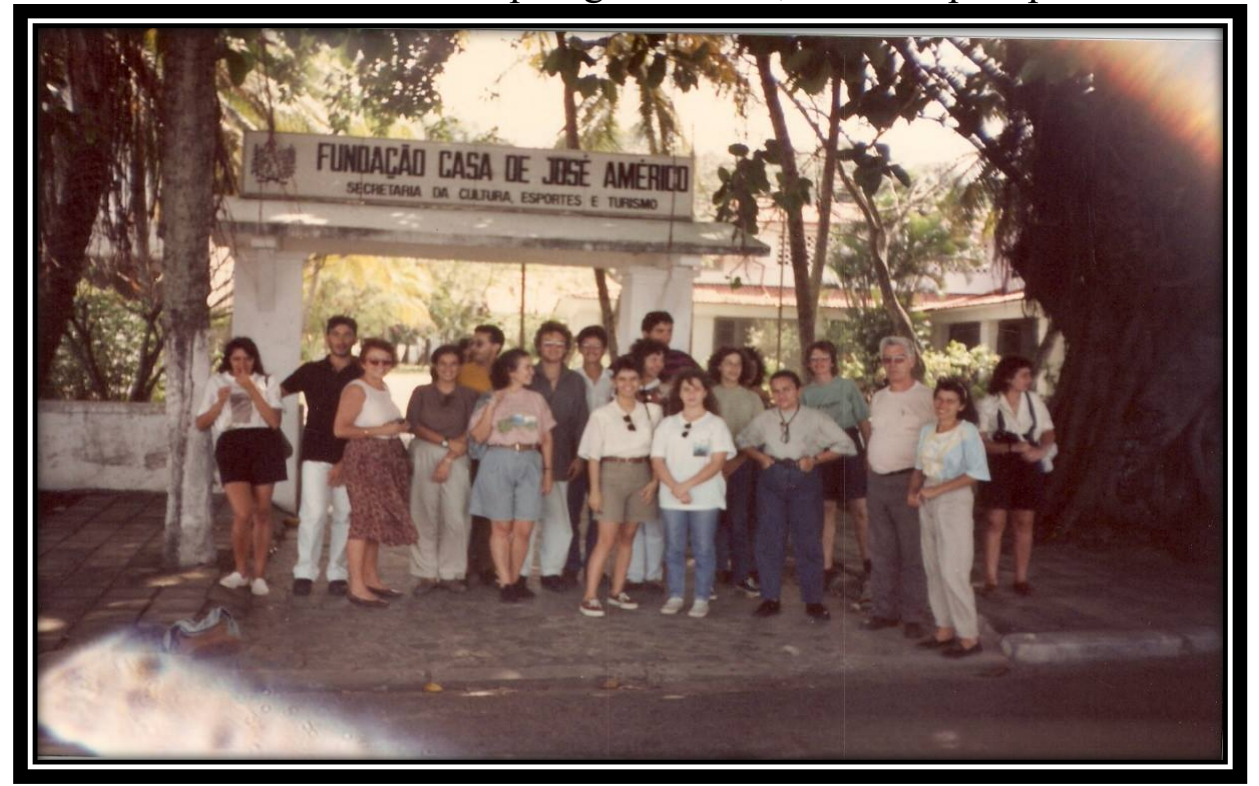

Fonte: Arquivo PET Antropologia

Vinculado ao então Departamento de Sociologia e Antropologia, no ano de 1988, hoje, Unidade Acadêmica de Ciências Sociais, o Programa de Educação Tutorial, ligado ao MEC e à CAPES, tem por filosofia a formação integral do aluno do curso de graduação em Ciências Sociais, tanto no que diz respeito a sua preparação intelectual para ingressar numa pós-graduação e seguir uma carreira acadêmica, quanto à sua formação ética e cidadã, enquanto sujeito comprometido com a sociedade envolvente, munido na prática incessante do exercício do trabalho em grupo. A ideia precípua do PET é o trabalho grupal, o trabalhar e aprender juntos.

Como já dito, o número máximo de alunos bolsistas permitidos na primeira fase do programa era de doze, sendo possível ainda, depois de reforma recente, a inserção de até seis voluntários, que devem assumir os mesmos compromissos que os bolsistas, selecionados a partir de criterioso exame de admissão que leva em consideração o rendimento escolar, o grau de interesse, motivação e disponibilidade de tempo para dedicar-se, por pelo menos vinte horas semanais, às atividades previstas no Programa. Os alunos voluntários, além de desenvolverem as mesmas atividades dos bolsistas, poderão ser 'elevados' à condição de bolsistas após a saída de bolsista por desligamento, em geral por conclusão de curso. 
Foto 3 - Petianos na UFPE para participar da SBPC - 1993. Os três Petianos atualmente são doutores e professores da UFCG e UFPB.

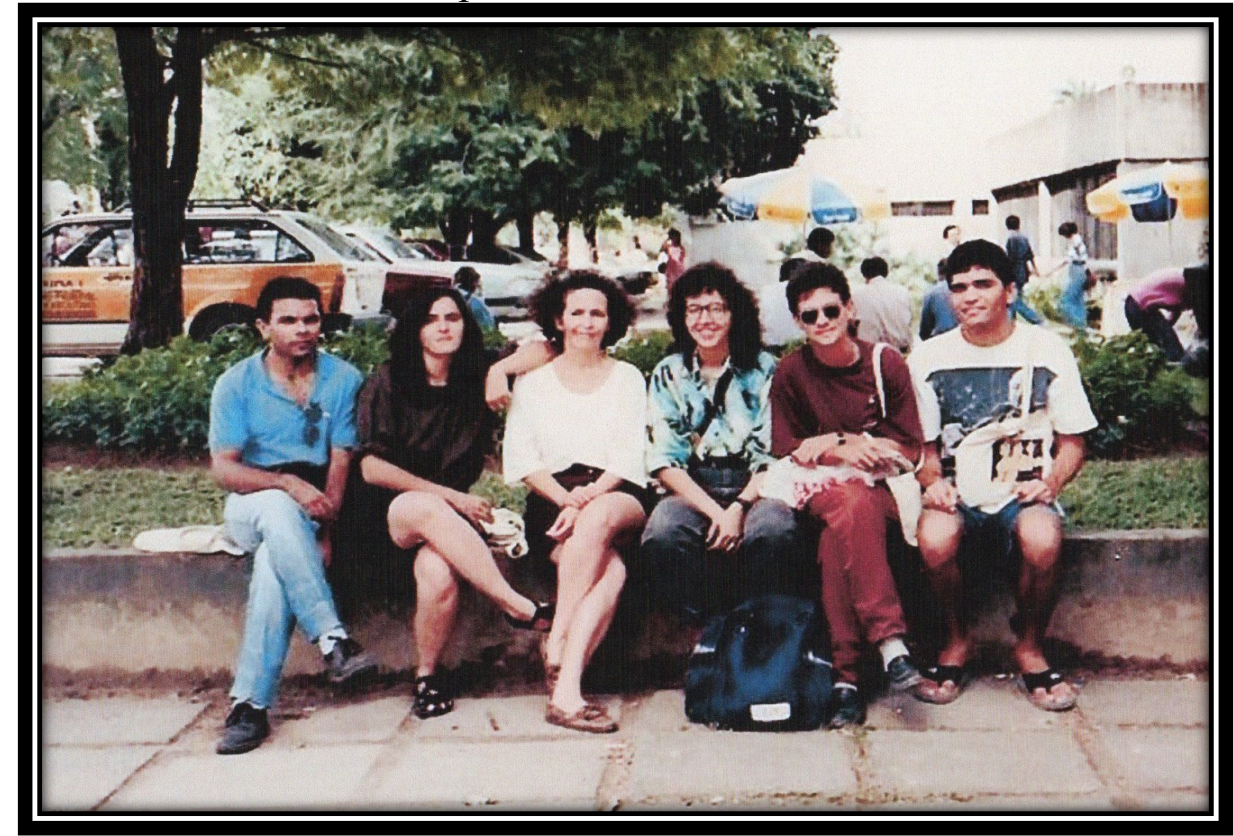

Fonte: Arquivo Elizabeth Lima

O Programa em seus primeiros anos, antes de consolidar o número de doze bolsistas, admitia seleção anual para ingresso de quatro novos integrantes, até totalizar o número de doze. Uma vez integralizado, um novo bolsista só seria inserido quando surgisse alguma vacância.

Como a ideia básica do PET é aprimorar o conhecimento dos alunos, o que se investia nesse período, em termos teóricos, era o estudo aprofundado das teorias antropológicas. Os principais teóricos das escolas e suas obras foram lidos e discutidos na integra, oferecendo-se aos petianos excelente formação na área de Antropologia.

Foto 4 - Petianos reunidos com a tutora na sala do PET-Antropologia, no ano de 2005. Destes, cinco atualmente são doutoras e uma professora da UERN e outra na UFAL.

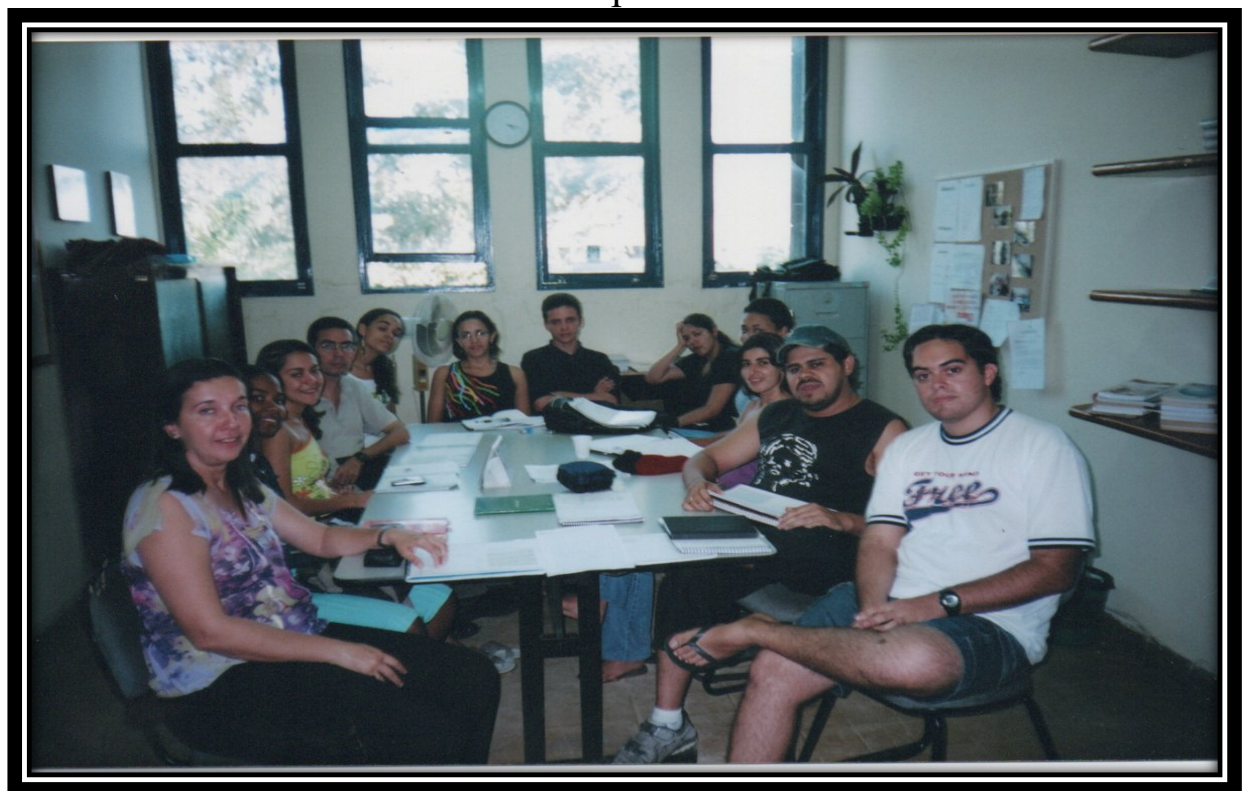

Fonte: Arquivo Elizabeth Lima 
A cada grupo de quatro alunos inseridos no PET, a estrutura de trabalho acadêmico era seguir um cronograma de leituras semestrais, previamente definido, para cada "escola antropológica", de forma que as vezes, em um único ano, acontecia de ter três turmas, cada uma delas discutindo uma escola da Antropologia. Isso sempre exigiu do tutor grande empenho e dedicação para acompanhar as leituras e discussões de vários manuais e etnografias antropológicas em um mesmo semestre.

É possível afirmar, sem dúvidas, que a formação teórica oferecida pelo PET é completa. As etnografias de antropólogos clássicos eram lidas e discutidas na íntegra e os bolsistas ainda produziam monografias a partir delas. Isso permitia que, ao concluir o Programa, o petiano obtivesse uma sólida formação acadêmica e estivesse bem preparado para concorrer, com êxito, em um Programa de PósGraduação em Antropologia. Nesse sentido, o campus II da Universidade Federal da Paraíba e doravante, em 2002, Universidade Federal de Campina Grande tornou-se e continua a ser referência acadêmica na formação de alunos de graduação nos estudos antropológicos, por meio de uma sólida e completa formação.

Ao final de cada semestre, o petiano tinha por atividade produzir uma monografia sobre um tema referente à escola antropológica discutida e deveria defender oralmente o seu trabalho em uma atividade pública e com a presença e participação de um professor arguidor, preferencialmente, um colega da área de Antropologia. Para essa atividade, o Programa sempre conseguiu envolver todos os professores da área, seja na função de orientador, seja na de arguidor.

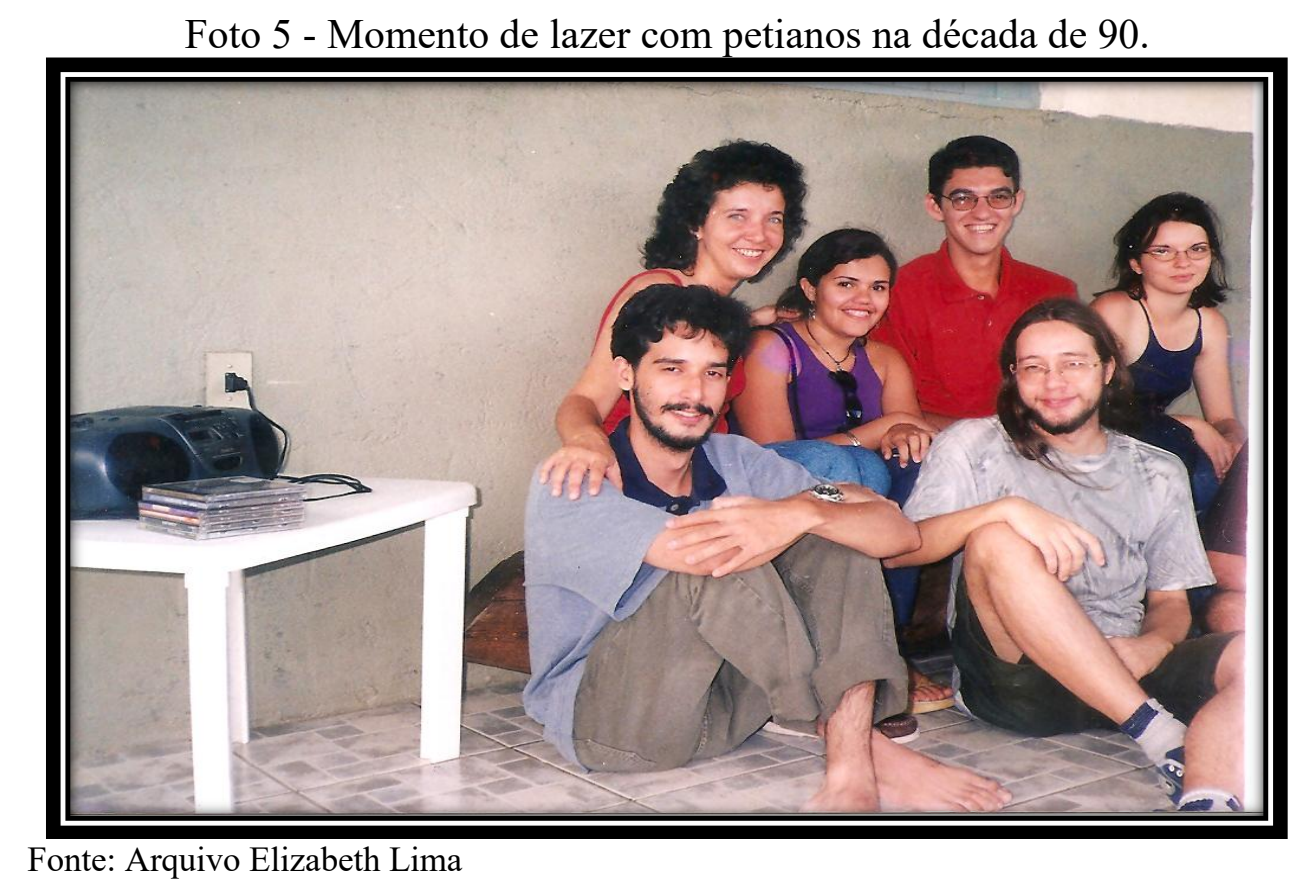

Os resultados do trabalho desenvolvido pelo PET são tão exitosos que, só para exemplificar, da imagem acima, os três petianos hoje são doutores em Antropologia, todos três professores universitários da UFCG, UFPE e UERJ, e a pestana, à direita, é doutora em Ciências Sociais e também 
professora universitária da UERN. Cumpre ainda registrar, como exemplo, que dois dos atuais professores de nossa Unidade Acadêmica, Vanderlan Francisco da Silva e Rogério Humberto Zeferino foram petianos e são atualmente professores da área de Antropologia da UFCG e tutores do PET. Desatacamos ainda que algumas das monografias produzidas durante os estudos semestrais no PET Antropologia acabaram por ser publicadas em forma de livro, inclusive obtendo premiações ${ }^{4}$ acadêmicas importantes no Nordeste.

\section{REDEFINIÇÕES E NOVAS REGRAS PARA UM PROGRAMA QUASE EM EXTINÇÃO}

No final de 1999, o Programa PET deixou de ser ligado à CAPES/SESU e passou a ser coordenado pela Secretaria de Educação Superior do Ministério da Educação - SESu/MEC, mais especificamente pelo Departamento de Modernização e Programas da Educação Superior - DEPEM. No ano de $2005^{5}$, o nome da sigla também deixou de significar PET- Programa Especial de Treinamento, e passou a ser PET - Programa de Educação Tutorial:

Regulamentado pela Lei $\mathrm{N}^{\circ} 11.180$, de 23 de setembro de 2005, e pelas Portarias MEC $\mathrm{N}^{\circ}$ 3.385 , de 29 de setembro de 2005 , e $\mathrm{n}^{\circ} 1.632$, de 25 de setembro de 2006, o PET destina-se a apoiar grupos de alunos que demonstrem potencial, interesse e habilidades destacadas em cursos de graduação das Instituições de Ensino Superior - IES. (Manual de Orientações Básicas, p.04)

Essas modificações no significado da sigla e nos vínculos aos órgãos ligados ao Programa também foram acompanhadas por uma nova estrutura burocrática e de avaliação dos Programas Comissão de Avaliação e Acompanhamento (CLAA) -, principalmente, no que diz respeito a sua avaliação anual:

O Programa de Educação Tutorial constitui-se, portanto, em uma modalidade de investimento acadêmico em cursos de graduação que têm sérios compromissos epistemológicos, pedagógicos, éticos e sociais. Com uma concepção baseada nos moldes de grupos tutoriais de aprendizagem e orientado pelo objetivo de formar globalmente o aluno, o PET não visa apenas proporcionar aos bolsistas e aos alunos do curso uma gama nova e diversificada de conhecimento acadêmico, mas assume a responsabilidade de contribuir para

\footnotetext{
" O livro "Crepúsculo antropológico", formado por seis capítulos escritos originalmente como monografias semestrais no PET Antropologia, de autoria do ex-petiano Vanderlan Silva, foi agraciado com o prêmio de melhor trabalho acadêmico do Rio Grande do Norte de 2008, no Concurso Rota Batida III, promovido pela Fundação Ving-Un Rosado, com patrocínio da Petrobrás e apoio do Governo Federal, Governo do Rio Grande do Norte e da Lei Câmara Cascudo.

5 Além da Lei 11.180 de 23/09/2005 da Presidência da República, outras Portarias e Resoluções foram emitidas para regulamentar as atividades do PET desde então: Lei $\mathrm{n}^{\circ} 11.180$, de 23 de setembro de 2005 - Institui o Programa de Educação Tutorial - PET; Portaria n ${ }^{\circ}$ 976, de 27 de julho de 2010 - Atualizada pela Portaria ${ }^{\circ} 343 / 2013$ - dispõe sobre o Programa de Educação Tutorial - PET; Portaria n 343, de 24 de abril de 2013 - Altera dispositivos da Portaria MEC $n^{\circ}$ 976, de 27 de julho de 2010, que dispõe sobre o Programa de Educação Tutorial - PET; Resolução n 36 , de 24 de setembro de 2013 - Estabelece os procedimentos para creditar os valores destinados ao custeio das atividades dos grupos PET aos respectivos tutores; Resolução/CD/FNDE $n^{\circ}$ 42, de 4 de novembro de 2013 - Estabelece orientações e diretrizes para o pagamento de bolsas a estudantes de graduação e a professores tutores no âmbito do Programa de Educação Tutorial (PET).
} 
sua melhor qualificação como pessoa humana e como membro da sociedade. (Manual de Orientações Básicas, 2004, p. 5)

Cabe aqui fazer o registro que durante os cinco primeiros anos do governo de Fernando Henrique Cardoso, 1995 a 2000, os Programas PET passaram por grande crise, chegando a anunciar o seu fim. Bolsas de tutores e de bolsistas foram suspensas por longos cinco anos e, se não fosse a determinação de tutores, petianos e instituições universitárias que se uniram na defesa de continuidade do programa e que prosseguiram na realização de suas atividades sem nenhum apoio financeiro e/ou logístico, certamente o programa não mais existiria. Foram anos de luta e de muito ativismo político dentro e fora das IES em sua defesa.

Neste contexto de redefinições e crises institucionais e estruturais do Programa PET, foram mudadas também as atividades exigidas; para tanto, o PET passou a realizar, a partir do ano de 2004, obrigatoriamente, as atividades baseadas no tripé: ensino, pesquisa e extensão, unidas a um tema de trabalho anual que devia, obrigatoriamente, envolver todos os bolsistas e voluntários nas três atividades:

O PET, ao desenvolver ações de ensino, pesquisa e extensão, de maneira articulada, permite uma formação global, tanto do aluno bolsista quanto dos demais alunos do curso, proporcionando-lhes uma compreensão mais integral do que ocorre consigo mesmo e no mundo. Ao mesmo tempo a multiplicidade de experiências contribui para reduzir os riscos de uma especialização precoce. (Manual de Orientações Básicas, 2004, p.06)

Sob a lógica desse novo tripé: ensino, pesquisa e extensão e sua indissociabilidade, o ensino

[...] deve ter como horizonte a aprendizagem, processos independentes que dão corpo a uma relação em que a participação ativa do aluno, como agente de um ato criativo e realizador, é imprescindível e onde se constroem novas capacidades, com transformações mútuas entre alunos e professores, haja vista as experiências diferenciadas desses atores. (Martins, 2007, p. 18-19)

Apesar dessa nova estrutura de trabalho parecer ser promissora, e em certo sentido foi, houve uma grande mudança na ênfase sobre que tipo de perfil de aluno PET se desejava formar, ou seja: Já não tinha mais a finalidade de que o aluno se engajasse numa pós ou no ensino superior como prioridade da formação; a filosofia central passa a ser a de assumir uma característica cada vez mais dirigida às atividades extracurriculares:

Outra iniciativa de inovação em âmbito nacional é o Programa de Ensino Tutorial (PET). Este tem como diferencial o caráter exclusivamente extra-curricular de suas atividades e em seu formato atual, conta com a possibilidade de permanência mínima de dois anos para o graduando, na qualidade de bolsista (e/ou colaborador sem bolsa), para desenvolvimento de projetos coletivos que articulam a tríade ensino/pesquisa/extensão. O PET apresenta grande afinidade em seu percurso histórico com a pedagogia da problematização (PP) que, por sua vez, tem inspiração em ideias e fundamentos da pedagogia de Freire (1975). (Kato; Faggian, 2007, p. 39). 
Pensar sobre a dimensão política da educação e a relação intrínseca entre educação e sociedade parece ser a ênfase desse novo formato de educação tutorial desde então. O olhar para fora da instituição universitária e a descoberta de um cenário real de relações, ações coletivas, práticas rituais e costumes que necessitam ser desvendados se manifesta para os petianos e seu tutor com todas as suas riquezas e contradições, e neste processo

\begin{abstract}
o ensino-aprendizagem significativo se dá não apenas no sentido de retirar os elementos que conferirão significado e direção ao exercício da práxis, mas também na possibilidade de formação da consciência da mesma; daí o caráter fortemente político do trabalho pedagógico. Assim, ensino-aprendizagem e investigação temática aparecem como momentos indissociáveis de um mesmo processo: o conteúdo deve estar sempre se renovando e ampliando, voltado criticamente à realidade não mais concebida como estática, mas em transformação e com todas as suas contradições. (Kato; Faggian, 2007, p.39).
\end{abstract}

Por fim;

O princípio da Educação Tutorial, entendido como ação de acompanhamento, de orientação, de cuidado pedagógico e de implementação de atividades construtivas, que visam proporcionar o desenvolvimento pessoal, profissional e institucional dos atores envolvidos docentes e discentes, vivenciado pelos grupos PET, evidencia, portanto, que as diretrizes do programa fortalecem as práticas pedagógicas fundamentadas na formação de profissionais/cidadãos que possam atuar de forma coletiva e que sejam agentes capazes de transformar o mundo que os rodeia. A capacidade de transformação exige, muitas vezes, um pensar diferente, que proporciona mudanças nas práticas de ação e atuação na sociedade. (Fechine; Lima; Araújo, 2007, p.47).

Um fato que merece destaque é que, nessa nova estrutura, o PET aumentou o peso das atividades burocráticas, o Programa passou a ser muito avaliado, investigado, submetido a uma exaustiva avaliação semestral e anual, por diferentes instâncias marcadas por uma forte pressão para não ter rebaixada a sua nota, criando, inclusive, aquilo que jamais deveria existir e não existia no contexto dos Programas PET, que era a competição entre os Programas dentro e fora das IFES.

O tutor, antes escolhido com a anuência da área, agora passa por um processo de seleção, com Edital de inscrição, que prevê a composição de uma banca de avaliadores, na maioria externa à unidade acadêmica da área de origem do candidato; apresentação de memorial e realização de entrevista. Tal processo promove a disputa e, muitas vezes, possíveis animosidades entre os colegas. Antes dessa nova estrutura, tal escolha era motivada pelo próprio desejo do professor em contribuir com o programa.

A adaptação e a transição para essa nova "Filosofia do Programa" e de definição das atividades de ensino, pesquisa e extensão não foi fácil, nem para o tutor, tampouco para os bolsistas. Alguns petianos e tutores preferiam continuar com a formação aprofundada nas teorias antropológicas, mas isso não era mais possível, isso porque, doravante, a equipe do PET tinha que se reunir e escolher um tema de estudo que abrangesse as atividades de ensino, pesquisa e extensão. 
Na primeira fase do PET-Antropologia, dos anos de 1988 a 2004, a formação do petiano era basicamente e sobretudo de ensino, ou seja, o aluno era levado a estudar e aprofundar as principais escolas do pensamento antropológico. Com esse cabedal de conhecimento, ele estava preparado para concorrer a uma pós-graduação e a concursos para docência na área de Antropologia. Isso é tão verdade que, como se demonstrará abaixo, boa parte do quadro de professores que atualmente ministram aulas nas Universidades não só da Paraíba, mas do Nordeste, são egressos do PET. De aproximadamente cento e sessenta estudantes que fizeram parte do PET Antropologia ao longo desses trinta e dois anos de sua existência, aproximadamente setenta por cento deles ingressaram na pósgraduação nos anos imediatamente subsequentes às suas formaturas na graduação em Ciências Sociais, muitos dos quais se tornaram docentes do ensino superior numa vasta gama de universidades e faculdades em muitos estados brasileiros. Há ainda outros que foram trabalhar como técnicos altamente qualificados em instituições estatais brasileiras, após terem sido aprovados em concurso público.

Com a reestruturação do Programa PET, o grande desafio agora passou a ser não só definir um tema que fosse atrativo e importante para os petianos, como também que fosse amplo o suficiente para atender ao tripé: ensino, pesquisa e extensão.

Sobre o papel da Extensão para os Programas PET, esta foi definida pelo Fórum de Extensão dos Pró-Reitores das Universidades Públicas - FORPROEXT e ela é pensada como

\footnotetext{
Princípio educativo que contempla o processo de produção do conhecimento por meio da dimensão investigativa e do contato com o real. A ênfase no processo, o esforço no coletivo institucional e não ao assistencialismo material e intelectual são elementos estruturantes de uma visão atual e progressista da extensão universitária. (Martins, 2007, p. 19).
}

Traçar caminhos satisfatórios para o cumprimento dessa visão, extremamente pertinente sobre o significado da extensão universitária, foi, sem dúvida, um desafio para o Programa PETAntropologia. Entrementes, podemos destacar, por exemplo, duas experiências interessantes nesse novo formato do Programa: No ano de 2004, ficou definido, no Planejamento Anual de Atividades, trabalhar com a construção das ideias do masculino e do feminino, principalmente na Antropologia Americana. Para tanto, foram lidas e discutidas as etnografias de Margaret Mead, Sexo $e$ Temperamento e Macho e Fêmea. Dessas leituras, a partir, principalmente, das três etnografias de três culturas na Nova Guiné, nos anos 1930, os Arapesh, os Mundugumor e os Tchambuli, foi montada uma atividade de extensão a ser realizada na escola estadual de um município próximo à Campina Grande, Boa Vista, e lá foi discutido, com os alunos do terceiro ano do Ensino Médio, a construção do masculino e do feminino enquanto uma construção cultural. Tal atividade foi extremamente interessante porque, num primeiro momento, os petianos foram levados a ter que desconstruir as noções de feminino e de masculino naturalizadas por sua própria cultura, e a terem que repassar para 
os alunos da escola a ideia de gênero como uma construção cultural (Scott, 1986), sendo necessário, portanto, desnaturalizar o próprio pensamento:

\begin{abstract}
Com esta comparação, Mead buscou rebater o essencialismo de senso comum que prevalecia nos Estados Unidos de que as mulheres seriam naturalmente mais aptas a cuidar de crianças, por exemplo. Nos termos do culturalismo de sua época, Mead afirmava que a cultura moldava os temperamentos, as personalidades, concluindo que não era a base biológica - o corpo, nem uma parte dele, como os hormônios - que explicaria as personalidades de homens e mulheres em diferentes culturas: o fator determinante seria o aprendizado cultural. (Almeida, 2020, p.35).
\end{abstract}

A atividade de "desconstrução" das categorias de gênero masculino e feminino, acima referida, em nosso entender, ajudou a cristalizar nas alunas e alunos uma nova forma de se pensar e pensar o outro em termos de gênero. Tudo foi questionado, problematizado, criando um ambiente de empoderamento, principalmente para as alunas, que viram a possibilidade de ficarem libertas das amarras da construção de gênero que as colocam presas a uma falsa construção do "amor materno" (Badinter, 1985); ou que naturaliza o sentimento, a afetividade, a sensibilidade, a timidez, a paciência, o altruísmo, a resiliência como um atributo do feminino; e a força, a coragem, o enfrentamento, a capacidade de luta, o talento para a oratória como um atributo do masculino.

A pesquisa, o ultimo tripé da nova estrutura do Programa PET, também levou o PETAntropologia a imprimir um redimensionamento às suas atividades, e esta "deve integrar os projetos pedagógicos dos cursos, como princípio educativo que atravessa a formação do aluno no dia a dia, no cotidiano da sala de aula, nas tarefas acadêmicas, ampliando-lhe os campos de ação, de reflexão e de autonomia intelectual." (Martins, 2007, p.19).

Uma atividade desenvolvida pelo PET que pode ilustrar a inserção da pesquisa foi a investigação sobre a prática do ecumenismo por ocasião do Encontro para a Nova Consciência, evento que se realiza anualmente na cidade de Campina Grande, durante o período carnavalesco. Os petianos fizeram pesquisas durante o evento, coletaram material fotográfico, realizaram entrevistas, fizeram Trabalho de Campo e Pesquisa Participante e produziram artigos muito interessantes sobre o movimento. Artigos estes que foram, no ano seguinte, apresentados durante o evento da Nova Consciência.

Outro exitoso tema de pesquisa foi quando o grupo resolveu trabalhar com o tema das Festas e Cultura Popular, no ano de 2007. Temas como: religiosidade popular, literatura de cordel, a festa do Maior São João do Mundo e o artesanato nordestino foram trabalhados. Como resultado das discussões teóricas, os petianos foram a campo, coletaram dados sobre esses temas e produziram seus trabalhos, e estes foram debatidos, posteriormente, por um professor arguidor, e banners foram expostos para divulgar os diferentes temas trabalhados e selecionados. Tal atividade marcou os dezenove anos de existência do Programa. 
Foto 6 - Ex-petianos - 2007. Destes, as duas moças à esquerda e as outras duas à direta são doutoras e duas delas professoras universitárias de Antropologia na UERN e UFAL.

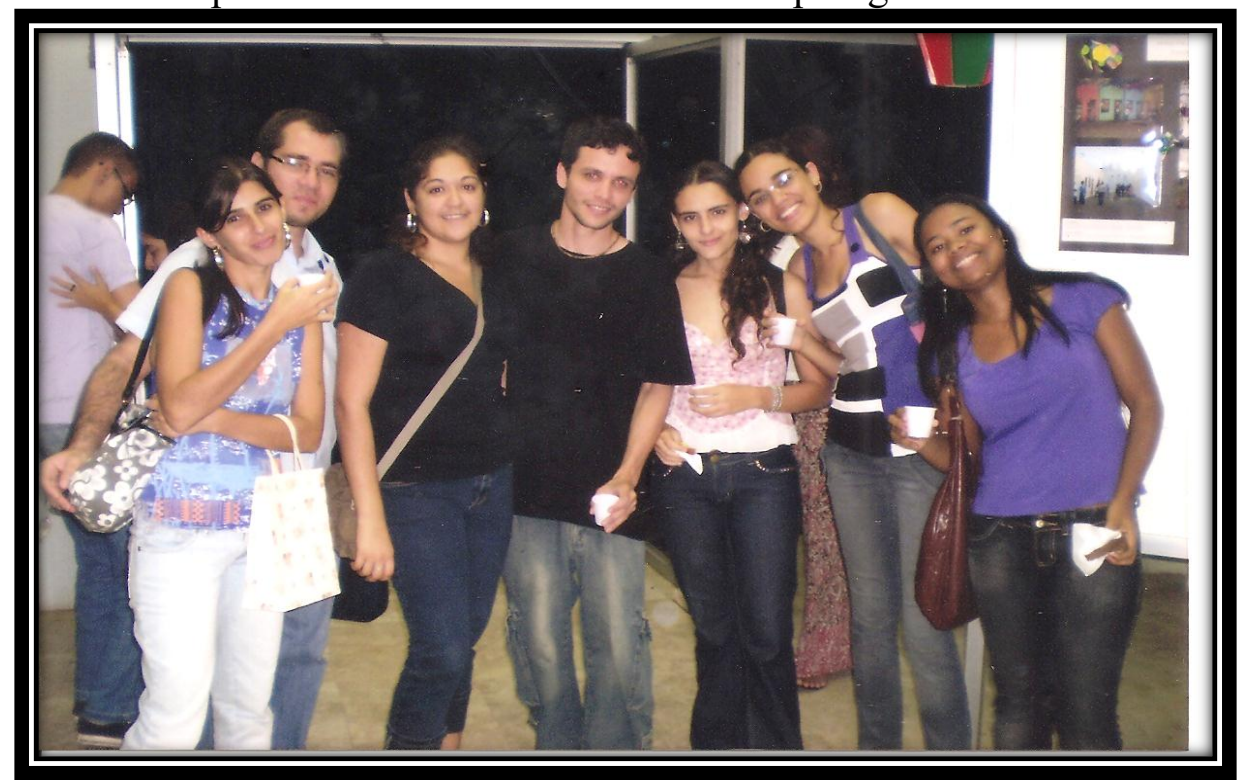

Fonte: Arquivo Elizabeth Lima

Foto 7 - Turma do PET-Antropologia com o seu tutor Vanderlan da Silva - março de 2020

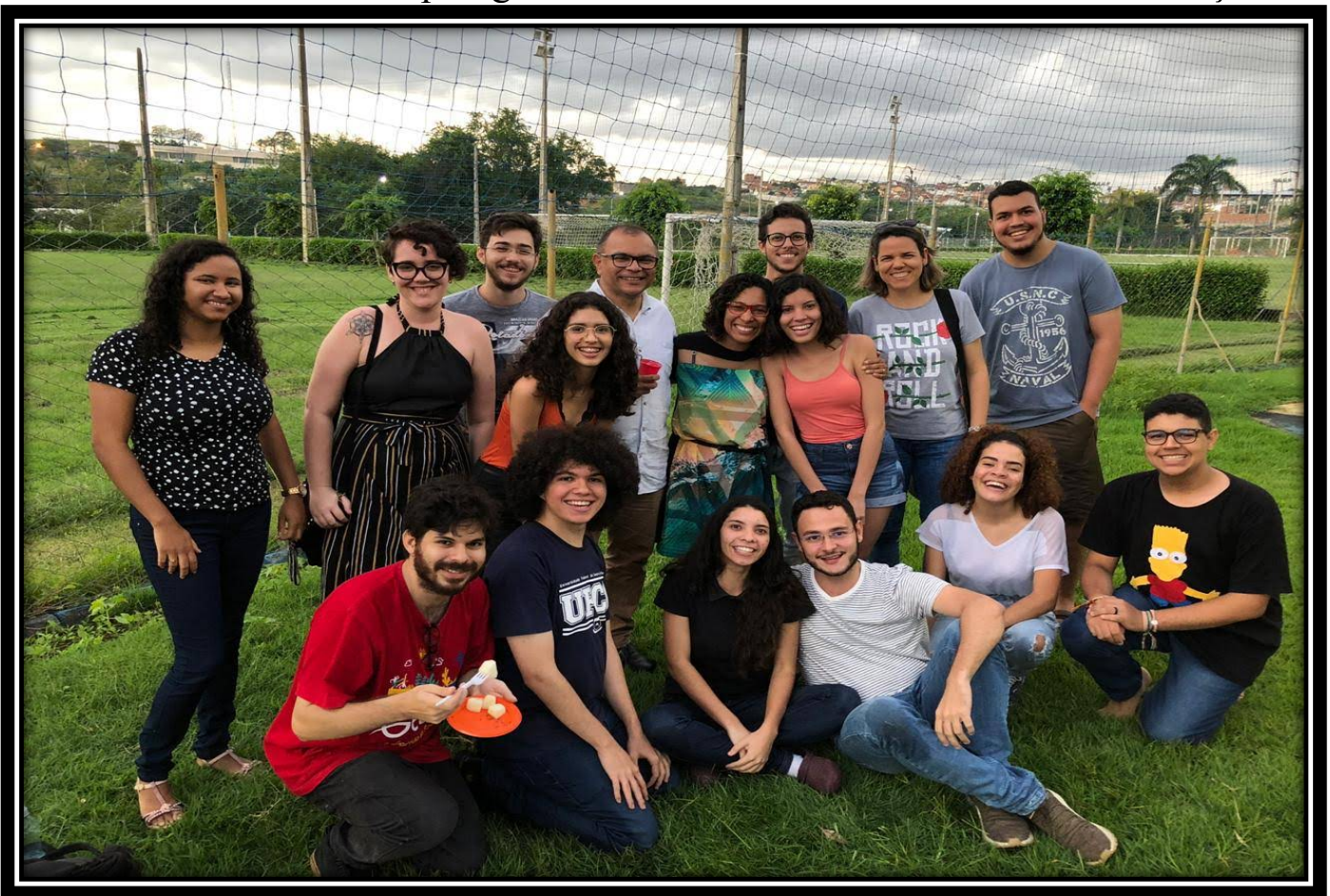

Fonte: Arquivo do PET Antropologia

Essa atividade levou os petianos a não só exercitarem a pesquisa, mas a conhecerem melhor a chamada "cultura popular local", através da realização da festa do "Maior São João do Mundo". Ou seja, um olhar para o local, para a reflexão de um tema "próximo" e "familiar" dos petianos.

Mais recentemente, pesquisas sobre o universo culinário campinense, os usuários do Bolsa Família, as práticas de lazer em praças municipais, os invisíveis nas festas juninas no Parque do Povo foram realizadas pelo grupo e com igual êxito de aprendizagem. 


\section{O EMPODERAMENTO PESSOAL E ACADÊMICO DAS PETIANAS E O FORTALECIMENTO DA ANTROPOLOGIA NO NORDESTE}

A propósito das experiências vividas pelas petianas nas atividades de extensão, anteriormente descritas, principalmente sobre a construção/desconstrução de gênero masculino e feminino, resolvemos, para escrever este artigo, realizar algumas incursões etnográficas e contatamos, via redes sociais, WhatsApp e Facebook, com ex-petianas, de diferentes anos de inserção no PET, desde as primeiras turmas até as últimas, de diferentes inserções no Curso de Ciências Sociais, e dez delas acolheram e responderam os nossos questionamentos.

Interessou-nos indagar-lhes sobre a sua experiência no Grupo PET, sobre seu lugar social e de gênero ao participar do Programa e o que o Programa as ofereceu enquanto empoderamento do feminino, na experiência cotidiana no PET, no Curso de Ciências Sociais e na vida profissional, como antropólogas.

Para garantir o anonimato das depoentes, resolvemos utilizar pseudônimos. Assim optamos pelo uso de nomes de plantas para identificá-las no texto. Alguns relatos foram adquiridos por escrito, outros, em depoimentos orais, que uma vez transcritos, buscaram ao máximo a fidedignidade dos relatos construídos.

Ao serem indagadas sobre a sua inserção no PET, algumas de nossas informantes, de maneira geral, traçaram, antes, um rápido histórico de como o Curso de Ciências Sociais surgiu para elas para depois narrarem sobre sua inserção no Programa PET:

Falar do Pet-Antropologia é voltar um pouco no tempo quando ainda na escolha do curso que iria tentar na UFCG. E queria muito um curso na Federal. O que mais chamava atenção era Ciências Sociais. E ainda meu namorado, na época, também fazia esse Curso. Passei no vestibular e ingressei na universidade em 2006.2. Um mundo novo. Um universo de tantas possibilidades que a universidade era um encantamento. Os cursos de introdução foram importantíssimos para entender o que realmente queria no Curso. A antropologia me tomou. E com alguns semestres depois surgiu a oportunidade de realizar seleção para o PetAntropologia junto a colegas do mesmo período. O que me motivou mais ainda. Fui selecionada. (Hortênsia).

Meu ingresso no curso de Ciências Sociais da então Universidade Federal da Paraíba, campus II (hoje Universidade Federal de Campina Grande, campus I), aconteceu no primeiro semestre do ano de 1997. Isto gerou dentro da minha família naquela época certo mal-estar, pois havia deixado para trás o sonho mais dos meus pais do que meu de trilhar uma carreira no campo do Direito, curso de muito prestígio social em detrimento do de Ciências Sociais, ainda hoje muito mal visto, sendo considerado curso de maconheiro, bicha e sapatão, como ouvi muitas vezes de alguns "amigos" e familiares. Desse modo, já foi muita "ousadia" minha, uma jovem de 18 anos, uma legítima menina de classe média de cidade do interior, (pois Campina Grande continua sendo cidade do interior, por mais que isso desagrade muitos dos meus conterrâneos) saída do colégio de freiras, me impor e fazer o curso que eu de fato acreditava que era o da minha vocação. Enfrentei muitos boicotes familiares desde o início do curso, feitos estes na tentativa de me demover do meu objetivo, mas foi tudo em vão. Especialmente depois que tive a oportunidade de me inscrever, quando já estava cursando o segundo semestre do curso, na seleção para o PET Antropologia, programa que até então eu desconhecia (Rosa). 
Cumpre aqui fazer o registro de como os cursos da área de Humanas, e particularmente o Curso de Ciências Sociais, com raras exceções, continuam a ser discriminados por uma parcela de nossa sociedade. A representação que comumente se tem do Curso é muito bem ilustrada pelo depoimento de Rosa: "um curso de maconheiro, bicha e sapatão" e acrescentaríamos: desordeiros e comunistas. Ora, essa visão tão deturpada e ideologizada do curso, principalmente na visão do atual governo de Jair Bolsonaro, o qual desclassifica abertamente os Cursos de Humanas e Ciências Sociais, como "antros de ideologia da esquerda e de destruição dos valores da família e da religião", foram per se uma primeira luta que as petianas, e, certamente, os petianos tiveram que travar com suas famílias e a sociedade envolvente. A possibilidade de participar de um Programa com bolsa de estudo possivelmente fizeram ser revistos tais valores.

A realização de um exame de seleção para ingresso no PET permite não só o acesso a um Programa visto em nossa Unidade Acadêmica como de "primeira qualidade", em termos de formação acadêmica e pessoal, como também possibilita ao ingressante a oportunidade de vivenciar um conjunto de experiências e atividades definidas como extra acadêmicas que o faz amadurecer, não só academicamente, mas, sobretudo, pessoalmente. Vejamos alguns relatos de como se deu a inserção de algumas petianas no Programa e suas expectativas de ingresso no Programa:

\begin{abstract}
Participar do PET Antropologia para mim foi bem mais do que uma experiência acadêmica, foi a vivência de um momento especial de valorização na formação humanista. O programa chegou no curso de Ciências Sociais em 1988, era um projeto nacional da CAPES. Trazia aos alunos de graduação a possibilidade de uma formação que contemplava aprofundamento de leituras, prática e amadurecimento da escrita acadêmica, participação em congressos, participação e organização de eventos, produção para publicação e viagens de campo. A aprendizagem era múltipla e intensa. Marcou a vida acadêmica e pessoal de quem participou. (Acácia).

O PET me trouxe a mais rica experiência da minha formação acadêmica. Foi a partir dele que tive noção do que é publicar, participar de eventos acadêmicos, ter referência teórica, buscar conceitos. Viajei para o norte e para o sul do país, pelo PET. E foi a minha experiência no PET que me descortinou o mundo. (Orquídea).
\end{abstract}

O Programa PET, além de tudo que já foi dito sobre sua metodologia de formação acadêmica, tem servido, também, como um excelente ambiente de treinamento e aperfeiçoamento da convivência coletiva, do potencial da ação cultural, do ativismo social. O depoimento abaixo, ilustra bem essa ideia:

O PET Antropologia, por ter leituras que trazem a cultura como eixo central de uma sociedade, da identidade de um povo, o PET me trouxe esse lado humano, de analisar as Ciências Sociais. Além de me ver como uma mulher, cidadã, empodeirada, que se reconhece que está em uma cultura machista, patriarcal, o PET também me deu essa perspectiva profissional e de um ativismo cultural. Nós participamos de vários congressos, eventos, me lembro que participamos de uma manifestação em Brasília pela defesa do PET. Publicamos artigos, painéis, conhecemos tribos indígenas e tantas outras atividades. (Margarida).

A seleção estava prevista para selecionar duas pessoas. Muitos colegas de turma inscreveramse, assim como eu, e, no final, foram aprovados Flor em primeiro lugar, Canela em segundo 
e eu fui aprovada em terceiro lugar. Portanto, eles, assim que aprovados nessas classificações, ingressaram no PET, mas eu não. No entanto, fui convidada pela tutora para participar das reuniões do grupo para discussão dos textos teóricos que aconteciam duas vezes por semana. Como as reuniões não atrapalhavam meus horários de aulas, passei a me juntar aos petianos nessas discussões dos textos que eram previstos no cronograma de atividades do PET. Isso me fez muito bem, pois comecei a viver mais a vida na Universidade, pois até ali vivia só o ambiente da sala de aula e nada mais, nem sequer saia para lanchar com os colegas, era muito travada e vista como "nerd", bem pouco até entrava na Biblioteca Central, tirava meus textos na copiadora e me mandava para casa para ler e estudar, sempre somente em casa e sempre sozinha. Então, essa convivência inicial com os petianos, a maioria deles mais antigos no curso do que eu, mais conhecedores da Universidade do que eu, me descortinou uma UFPB bem diferente, mais viva, mais minha. (Os nomes em negrito são pseudônimos, Rosa).

Outra realidade encontrada, enquanto tutoras e tutores do Programa PET, é a percepção clara das condições sócio-econômicas de boa parte do quadro de nossos estudantes. Uma parte considerável de nosso alunado, e aí se inclua os petianos e petianas, advém dos extratos sociais mais carentes. Os pais são pobres e com muita luta tentam fazer com que seus filhos permaneçam no Ensino Superior, a maioria não logra sucesso e a bolsa do PET surge como a garantia de sustento desses alunos e alunas na Universidade:

Eu entrei no PET em meados do $4^{\circ}$ período. Eu concorri e foi um momento de muita alegria, porque uma bolsa do PET sempre foi muito concorrida, muito alunos gostariam de participar e eu me esforcei bastante e consegui entrar. E aí eu penso o PET sob duas perspectivas: no que ele representou e representa para mim. Sob o ponto de vista pessoal, eu venho de família pobre e na época eu me recordo muito bem porque o PET foi responsável pela minha permanência na Universidade, porque minha família é pobre; meu pai estava desempregado e minha mãe sustentava a casa vendendo marmitas. (...) Graças ao PET eu fui a única filha que entrou na Universidade e permaneceu. (Margarida).

É muito importante destacar a importância social que um Programa como o PET propicia aos alunos de baixa renda. Trazemos em nossa experiência de tutoria casos e mais casos de petianos cujos pais não tinham a menor condição de mantê-los na Universidade; muitos alunos sequer tinham o dinheiro para uma passagem de ônibus, vinham a pé para estudar; outros pediam dinheiro emprestado aos colegas para adquirir os materiais de estudo. Essa realidade reforça a importância de um Programa como este.

Outro aspecto relatado por uma de nossas depoentes foi a possibilidade da bolsa de estudos oferecida pelo Programa não só servir para manutenção econômica, mas, também, para a afirmação identitária de gênero e sexualidade, conforme discurso abaixo descrito:

Eu cheguei do interior vindo de uma cidade muito pequena e meus pais tinham muita dificuldade de me manter estudando e no segundo semestre eu fui aprovada para ser bolsista do PET e aquela bolsa trouxe sim, muitas conquistas porque logo mais eu comecei a namorar com a minha atual esposa e eu tive a oportunidade de ir morar com ela porque eu já estava recebendo aquela bolsa, então eu não tinha que dar satisfação aos meus pais, eu tive essa oportunidade de já no início do curso conseguir assumir um relacionamento homoafetivo. Então isso trouxe pra mim uma liberdade e uma afirmação dentro da minha família não só com uma mulher lésbica, mas também como uma estudante, uma antropóloga em formação. (Girassol). 
Algumas informantes também relataram que a participação no PET Antropologia, único PET do curso de Ciências Sociais, provocava certo "ciúme" e sentido de competição dentro do próprio curso. Na verdade, ao longo da existência do Programa na Unidade Acadêmica de Ciências Sociais, gerou alguns pequenos conflitos dentro da própria Unidade. Como a estrutura de nossa Unidade Acadêmica é composta por cinco áreas do conhecimento: Antropologia, Sociologia, Ciência Política, Direito e Filosofia, alguns chegavam a indagar: por que um PET em Antropologia? Por que só um PET em Antropologia? E isso, na experiência tanto docente quanto discente, em alguns momentos, gerou um desconforto. Algumas petianas chegaram a afirmar que sofreram discriminação, bullyng, por serem do PET, discriminação esta que partia tanto de alguns professores, como de colegas do Curso. Vejamos alguns desses depoimentos:

\begin{abstract}
Nas rodas de discussões teóricas, não era muito diferente; o lugar de fala das mulheres existia, ainda assim não eram vistas como tão intelectivas quanto a dos homens. Recordo-me vivamente de um professor que por sermos mulheres, para além de ser do PET, ironizava e satirizava a gente em sala de aula, experiência dele fracassada quando unidas nos reuníamos para estudar e através de muita dedicação e o que hoje damos o nome de "empoderamento feminino", conseguimos cursar a disciplina com êxito (Bromélia).

O PET-Antropologia empoderava naturalmente quem dele participava, na época a galera da esquina do grude chamava a gente (até em tom de chacota, o que nunca me incomodou, já que eu fazia parte também da galera do fundão) de "o crème de la crème do curso"; some-se a isso, o fato de que cada petiano, ao escolher um tema para estudo, acabava socializando suas experiências conosco e a riqueza teórica que acumulei naquele período até hoje me acompanha. (Carmélia).
\end{abstract}

Nós, tutores, pensamos o PET como um ambiente de formação acadêmica, mas também e, sobretudo, como um espaço de aprendizagem pessoal e relacional. Como os ingressantes do Programa são formados por grupos mistos de homens e mulheres, há que se construir, cotidianamente, relações de convivência baseadas no respeito e na harmonia, mas embates, conflitos, negativas e marcação das diferenças também fazem parte do social, são fontes geradoras do social. Assim, a questão não é o embate em si, o conflito por ele mesmo, mas como se lida e se reage a eles, no que diz respeito às diferenças de gênero dentro do PET, a partir das atividades executadas de ensino, pesquisa, extensão. Nessa direção, coletamos os seguintes depoimentos:

A minha entrada no PET se deu no ano de 2004. Lembro que compúnhamos um grupo heterogêneo, não houve disparidades quantitativas quanto a questão do gênero. Talvez, nós mulheres fossemos até a maioria. Durante os anos em que passei, não conseguia ou talvez não tivesse a maturidade necessária para compreender se existiam diferenças entre homens e mulheres. Entretanto, escrevendo hoje, percebo que existiam sim, nas divisões que a gente propunha para organização do espaço físico do PET, intencionalmente ou não, sempre os rapazes davam um jeito de não seguir, de adiar... $O$ que hoje interpreto sim como fortalecimento de padrões do que é ser homem ou mulher e o que compete a cada um fazêlo. (Bromélia) 
Tais padrões, "naturalizados" pela cultura, se não forem refletidos, questionados e superados, acabam por virarem modelos ideais sobre os lugares do masculino e do feminino, criando diferenciações claras sobre a ocupação desses espaços, o público e o privado, a rua e a casa, como nos ensinou DaMatta (1985).

Em outros termos:

(...) Ora, o poder é uma questão de voz, de discurso, de quem fala e de quem escuta. O poder também se cria por meio do ato de falar sobre o outro. A categoria do "outro" é criada em um discurso. Assim é que se cria a mulher ideal e, ao mesmo tempo, se demoniza a mulher fora do "ideal". (Tiburi, 2018, p. 108).

A próxima depoente destaca a predominância de uma relação equânime e respeitosa entre os petianos, independente de gênero.

Fazendo parte do PET Antropologia nossa convivência com os demais petianos, meninos, sempre foi tranquila. Apesar de sermos minoria eu e Canela sempre tivemos espaço de fala, tivemos essa fala validada entre as ações, atividades do Programa. Particularmente nunca me vi ou me percebi sendo vítima de atitudes machistas por parte dos meninos. Muitas vezes discordamos, discutimos e até disputamos, sim porque às vezes a disputa acontecia, mas nessas relações cotidianas o dado de gênero não nos definia. Outras vezes até tiramos onda um dos outros, fizemos chacota um dos outros, coisa muitíssimo compreensível diante de tanto tempo de convivência juntos, mas também aí nunca me vi, me senti menosprezada, desrespeitada por ser mulher. Fazíamos as atividades do PET juntos, inclusive a limpeza da sala do PET, sim porque até limpar a sala estava na nossa lista de atividades a serem feitas, e não existiam atividades das meninas por serem meninas ou atividades dos meninos por serem meninos, as atividades eram dos petianos, independente do gênero. ( $\mathrm{O}$ nome em negrito é um pseudônimo, Rosa).

As duas próximas depoentes destacam à condução tutorial dentro do Programa como um importante elemento na promoção da igualdade de gênero, no sentido da não permissão a que o grupo se distinguisse por esse recorte, levando a que um gênero se sentisse preterido em relação ao outro:

A minha inserção no Pet Antropologia foi muito tranquila em relação às questões de Gênero. O PET, apesar de ter uma presença masculina maior no número de alunos, contava com figuras femininas muito fortes na coordenação. Assim que entrei no curso me encantei com Antropologia e Cristina Marin, que me falou inicialmente do PET. Ao entrar no PET, conheci Elizabeth Christina, então coordenadora amável e dedicada, sempre dando espaço para o diálogo e respeito entre os integrantes do PET. Pouco tempo depois, o comando do PET passou para Mércia Rejane, professora exigente e igualmente competente, que manteve a mesma linha da coordenação anterior com muito respeito entre os petianos. (Tulipa).

Ao entrar no PET, fui beneficiada, embora fossemos minoria, por uma petiana mais antiga Papola, que já sabia muito bem como se colocar num ambiente em que os homens eram maioria, por esse motivo não fui reprimida em nenhum momento. $\mathrm{O}$ peso de sua fala era o mesmo de qualquer um dos meninos. As vezes em que senti algum desconforto, este não se deu em razão do meu gênero e sim, pela dedicação à leitura dos textos e contribuição nas discussões. Nas brincadeiras havia espaço para algum comentário machista, mas na hora do trabalho, no desempenho de nossas discussões e atividades, o respeito aos colegas estava garantido. Havia uma conexão muito boa entre os petianos, nos ajudávamos, e nos apoiávamos nas situações difíceis. Mas tudo isso só foi possível porque tínhamos na coordenação uma mulher forte, que usava sua autoridade de forma correta e disseminou entre os alunos o respeito ao outro. (Tulipa). 
As falas acima remetem-nos ao papel da tutoria no Programa PET, muito se diz sobre o lugar e a postura do aluno petiano ao participar de um Programa como este, no entanto, a outra parte que compõe essa atividade é de fundamental importância, pois compete ao tutor:

(...) um conjunto amplo e diversificado de valores, atitudes, habilidades e conhecimentos que, dificilmente, podem ser reunidos em um único modelo. Contudo, identifica-se preliminarmente que o tutor tem, dentre as suas várias atribuições, a destacada função de estimular o interesse acadêmico do aluno e identificar suas potencialidades e qualidades na perspectiva de promover a autonomia discente para analisar problemas, raciocinar criticamente e agir de forma ética e cidadã. (Martins, 2007, p. 15-16).

Dentre as falas das petianas inquiridas, uma reflexão merece destaque: a pouca participação feminina no PET em relação ao número de petianos, essa é realidade vivida por uma delas:

Com essa mudança o grupo do PET Antropologia que era composto por 12 estudantes, naquele momento passou a ter 10 meninos e 2 meninas. Pois é, apenas duas meninas, distribuição em termos de gênero bem desproporcional, o que gerava em mim e em Canela em algumas conversas que tivemos a pergunta: por que só nós duas??? Havia muitas meninas no curso de Ciências Sociais, mas ao longo de muitas seleções antes da nossa também passaram pelo PET poucas meninas e depois de nós duas só chegou outra menina, numa seleção realizada em 2000, quando o tutor já era o professor Rogério. (O nome em negrito é um pseudônimo, Rosa).

Refletir sobre a pouca representação feminina no PET Antropologia, na maioria da composição das turmas, a partir dos processos de seleção, é refletir sobre o próprio lugar de participação das mulheres em variados espaços, tais como no mundo do trabalho, na disputa político partidária, nos espaços de poder etc.

Faço ideia do caminho para a resposta para a pergunta que eu e Canela nos fazíamos. De certo que não percebíamos nem no curso nem na gestão do PET nenhum discurso de impedimento, nenhuma atitude pessoal de boicote, de desestimulo à participação das meninas. No meu caso, em particular, o estímulo, o incentivo, a aposta veio de um homem, de um professor do curso, de um ex petiano. Por outro lado, fato também era o de que para fazer parte do PET diante do que ele nos exigia, desde a carga horária presencial de dedicação semanal, ao tempo que dedicávamos ao PET fora da Universidade (em casa ao ter que dedicar tempo para estudar; nas viagens em função das atividades do PET; nos lugares em que estivemos para realizar as atividades do PET - campos de pesquisa, escolas etc - lembro que tivemos inúmeras reuniões administrativas aos sábados que nos custavam a manhã inteira deste dia da semana), faziam com que muitas das nossas colegas que eram participantes ativas da renda familiar e portanto tinham que trabalhar e estudar, muitas que eram mães, não tinham como se dedicar dessa maneira ao Programa - ainda mais porque somado a isso nós não podíamos ter reprovações em disciplinas, nem ter CRE abaixo de 7,0 (aliás a ideia era que ele fosse aumentando ao longo dos semestres), assim muitas das nossas colegas que, diferente de mim e de Canela - meninas de classe média - não tinham o privilégio de poder não trabalhar, que tinham filhos, casa e muitas vezes ainda um marido para ter que dar atenção, custando-lhes para isso tempo, não conseguiam se encaixar nesses requisitos. (Nome em negrito é um pseudônimo, Rosa). 
Tais dificuldades, muitas vezes se mostraram como uma "realidade" de nosso alunado, no entanto, é preciso deixar claro que essa pouca participação feminina nas seleções do PET e a sua consequente pouca representatividade, nada mais é que o reflexo de uma sociedade ainda marcada pelo machismo e sexismo, como pondera Tiburi (2018) e acrescenta Biroli (2010), ao ponderar sobre a situação de sub-representação feminina nos espaços de poder:

O desinteresse pela política, a falta de habilidade para o exercício de cargos públicos e o não pertencimento à esfera política são, assim, conectados em um conjunto de discursos que atendem a uma regularidade sem que se apresentem de forma homogênea. A oposição entre, de um lado, feminino e espaço privado, e, de outro, masculino e espaço público está na base desses estereótipos, confirmando divisões e hierarquias que colaboram para a marginalização das mulheres da e na esfera política. (Biroli, 2010, p. 273).

Construir uma reflexão sobre os lugares sociais, sobre a necessidade de desconstrução dos "lugares de gênero" como algo dado "naturalmente" segundo os gêneros masculino e feminino é algo que a convivência coletiva vivenciada no Grupo PET pode e deve suscitar. Por isso, sugerimos a nossas depoentes a relatarem até que ponto a participação no PET as ajudaram a ter consciência de seu lugar de gênero e de como e se essa consciência as empoderou, e obtivemos os seguintes relatos:

O PET me empoderou no sentido de fazer trilhar uma trajetória acadêmica, me permitiu um conjunto de saber teórico e prático para continuar fazendo ensino e pesquisa e me trouxe o ambiente e experiência necessária para hoje ser uma profissional que projeta-se no espaço acadêmico entendendo todas estas demandas do ser mulher e assim assumir o compromisso de construir um espaço diferente para outras mulheres. (Bromélia).

Quando eu entrei no PET nós lemos "A Sociedade Primitiva", de Lewis Morgan, e me chamou atenção o lugar social que as mulheres ocupavam e ai foi onde eu comecei a sentir uma vontade mais aguçada de estudar mais sobre as mulheres e como a academia nunca fica distante das nossas relações sociais o que me puxou ainda mais para pensar essa questão, foi uma experiência vivida na UFCG, eu passei por uma situação de assédio por parte de um professor da UFCG, fui assediada sexualmente, moralmente e tive que abrir uns processos e o PET surgiu como um ambiente de apoio e fui muito acolhida e as leituras me levaram a pensar sobre o lugar que nós mulheres ocupamos na sociedade. Então o PET foi crucial para mim hoje me sentir e ser feminista, me sentir mulher empoderada, uma mulher conhecedora de seus direitos e respaldada por leituras que me fazem ter total consciência do meu caminhar como ser humano. (Margarida).

O espaço de discussões no PET me fez cada vez mais enveredar sobre questões de gênero e política. Enquanto, estive no PET não sofri nenhum tipo de discriminação por ser mulher, mas minha percepção de mundo mudou com o aprofundamento de leituras e discussões sobre a temática. Essas discussões me impulsionaram a fazer minha monografia sobre o Blog da Dilma Rousseff quando ela se candidatou a presidência em 2010. O significado de ter uma mulher como presidente foi um marco na história política brasileira. E sua participação nas campanhas eleitorais foram importantes para apresentar uma sociedade que desqualifica, que discrimina o feminino. Ali foi claro, como a imagem da candidata passou por esse processo de avaliação pelos eleitores. Ser mulher, não ser casada, não ser delicada, não se dizer religiosa. Tudo isso foi uma forma de atacar a candidata como mulher. Apresentei minha monografia e continuei meu caminho de estudos por essas questões. No final de 2011 tentei seleção para o mestrado na Pós em Ciências Sociais. Passei na seleção e não foi diferente da monografia. Em 2012 fiz minha dissertação sobre a construção da imagem pública de uma candidata à prefeitura de Campina Grande, Tatiana Medeiros. Outra figura que trouxe muita repercussão sobre ser mulher. Inclusive ela teve o seu nome envolvido em vários boatos na cidade, para desqualifica-la como mulher e como candidata. Eu não chegaria a essas 
construções sem as motivações que o PET-Antropologia proporcionou. De abrir os olhos, em observar como as questões de gênero e política são muito tênues, delicadas. (Hortência).

Outras depoentes chamaram atenção para um empoderamento não tão somente a partir do recorte de gênero, mas sobretudo, pela possibilidade de se qualificarem intelectualmente e poderem chegar ao mercado de trabalho e competirem de igual para igual:

A questão de gênero colocada na minha passagem pelo PET, se coloca em vários sentidos. Primeiro, foi ali meu primeiro contato com a literatura, com a noção da categoria, com as percepções, com o treino do estranhamento, o que me fez perceber e entender as diferenças dos papéis. A questão pra mim se operou mais no campo da compreensão teórica que no empoderamento como mulher. Meu empoderamento, na minha percepção, foi mais ampla. Não apenas como mulher, mas como acadêmica, intelectual, caririzeira, futura profissional. (Orquídea).

Uma de nossas depoentes se ressentiu de uma dificuldade de tratamento igualitário, sem o recorte de gênero, tanto no âmbito interno do Programa como na própria convivência com os alunos do curso de Ciências Sociais.

Sobre a minha condição de mulher no PET Antropologia eu poderia dizer que ela foi muito ambivalente e um pouco do espelho do que acontece na sociedade de maneira geral. Eu tive sim oportunidade de empoderamento, mas ao mesmo tempo não estava livre do preconceito, principalmente, interno ao grupo e dentro do Curso de Ciências Sociais. É lamentável fazer essa afirmação porque o que se espera de um curso onde as pessoas estão ali para aprender a pensar criticamente e romper paradigmas e barreiras sociais. (Girassol).

Destacamos essa fala porque ela também faz um registro muito interessante de como é difícil romper com as tais diferenças de gênero, exatamente porque aqui estamos falando, sobretudo, de mecanismos de controle sobre o outro:

Tudo que é produzido pela subjetivação capitalística - tudo o que nos chega pela linguagem, pela família, pelos equipamentos que nos rodeiam - não é apenas uma questão de ideia, não é apenas uma transmissão de significações com polos maternos, paternos etc. Trata-se de sistemas de conexão direta entre grandes máquinas produtivas, as grandes máquinas de controle social e as instâncias psíquicas que definem a maneira de perceber o mundo. (...) (Guatarri apud Garcia, 2019, p.216).

Por outro lado, obtemos registros de que a convivência no PET, em um grupo misto de homens e de mulheres, não se marcava pelas diferenças de gênero, ao contrário, tais diferenças sequer evidenciavam-se:

Essa história que escrevo hoje aponta para o discernimento de que nunca precisei ser, dizer ou fazer no PET por ser mulher ou mesmo precisei deixar de ser, dizer ou fazer neste Programa por ser mulher. Aliás, um dos grandes legados que o PET me deixou e que marca o meu fazer profissional e mesmo a minha existência como pessoa, é o exercício da fala através da qual demarco meu ser e meu estar no mundo. Desde a minha entrada no PET Mércia soube me cobrar/estimular no sentido do falar, como do ouvir e do escrever (creio 
que nada mais adequado para um Programa de Treinamento em Antropologia) e hoje, nem de longe, lembro a menina que entrou no curso de Ciências Sociais em 1997. (Rosa).

(...) Eu nunca senti nenhum tipo de sexismo, ou de machismo, ou nenhum diferenciador em termos de gênero não. Pelo contrário, as mulheres também tinham total desenvoltura e oportunidade. Tudo era muito igual, igualitário. Pelo menos nas duas gestões que eu acompanhei, a de Bebete e de Mércia. Existia machismo, porque existem discursos machistas em todo lugar, mas não em relação a gente, porque existia entre a gente uma coisa tão fraterna, uma espécie de irmandade que a gente se protegia muito. (Papola).

Outras petianas destacaram a condução da tutoria como uma forma de estabelecimento de relações igualitárias dentro do Programa. Que, possivelmente, graças à condução das tutoras dentro e fora do PET, não se permitia espaços para práticas sexistas de gênero:

Como não sentir-se empoderada tendo como modelo professoras empoderadas como Salete, Cristina, Bebete e tantas outras que ministravam aula no curso? Impossível não absorver o empoderamento e não trazê-lo para o cotidiano. Foi graças à experiência no PETAntropologia que ingressei nas causas sociais e que rompi vários paradigmas dentro do mundo em que vivo; graças àquela experiência, orbito por vários mundos e travo conhecimentos e descobertas cotidianas. (Carmélia).

As três professoras, Cristina, Bebete e Mércia eram a representação do empoderamento feminino na academia. A professora que me tornei foi resultado do aprendizado com estas três professoras, não me refiro apenas ao aprendizado científico, na busca pelo conhecimento, mas como também na forma de me relacionar com meus alunos e colegas. (Tulipa).

Foto 8 - Os tutores Mércia Rejane, Elizabeth Lima, Vanderlan Silva, Marcio Caniello e Rogério Nascimento debatem PET Antropologia durante comemoração dos seus 30 anos, em novembro de 2018.

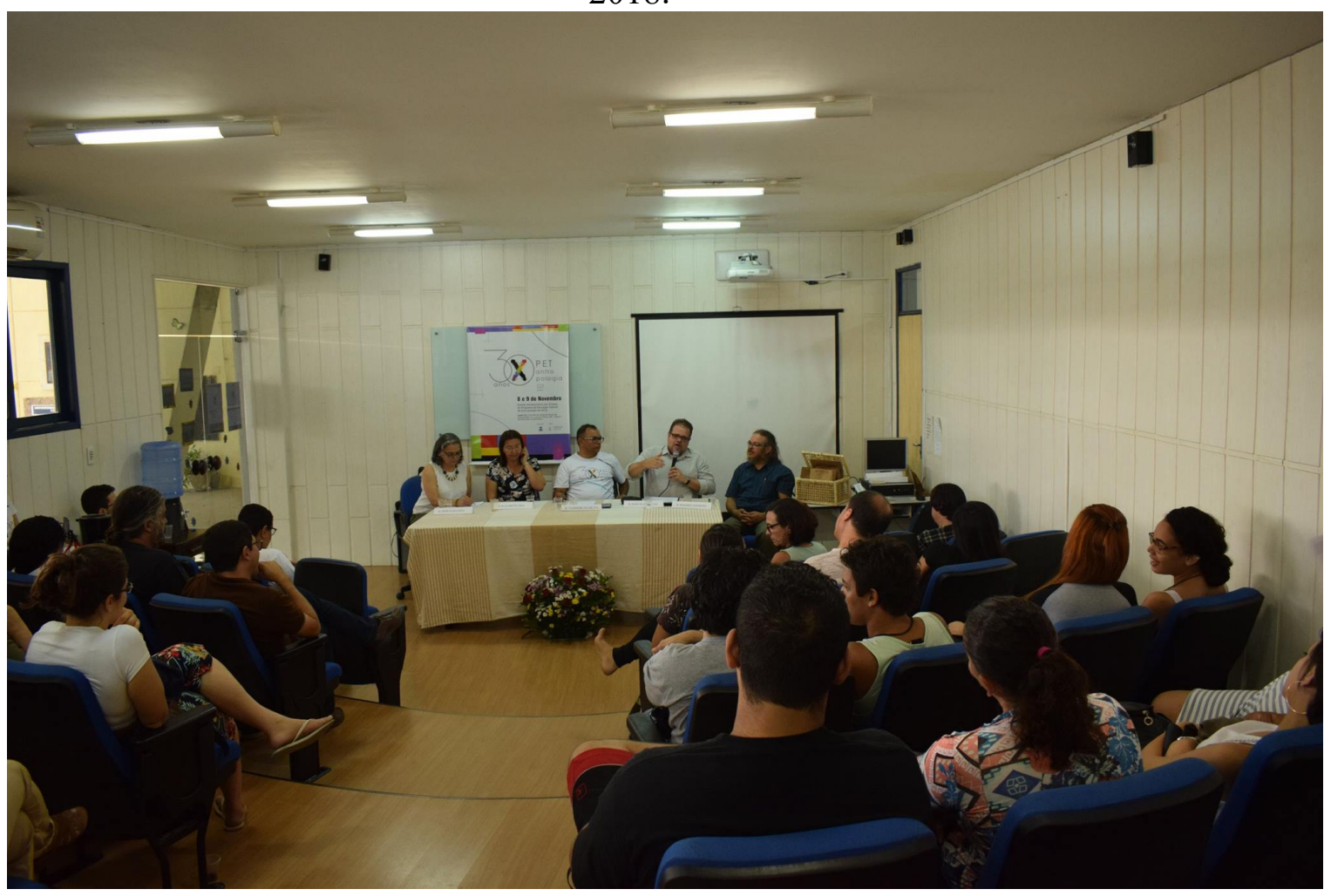

Fonte: Arquivo do PET Antropologia 
A partir dessas falas, acima descritas, recorremos a Cecília Sardemberg (2006), quando aponta para o caráter libertador que o empoderamento feminino possibilita às mulheres, pois não há como fugir ou negar que ainda vivemos sob a égide de uma sociedade marcada pelo sexismo, pelo machismo e pelas práticas de misoginia, nesses termos:

O empoderamento das mulheres implica, para nós, na libertação das mulheres das amarras da opressão de gênero, da opressão patriarcal. (...) O objetivo maior do empoderamento das mulheres é questionar, desestabilizar e, por fim, acabar com a ordem patriarcal que sustenta a opressão de gênero. (Sardenberg, 2006, p.02).

E ainda:

O empoderamento consiste de quatro dimensões, cada um igualmente importante mas não suficiente por si própria para levar as mulheres para atuarem em seu próprio benefício. São elas a dimensão cognitiva (visão crítica da realidade), psicológica (sentimento de autoestima), política (consciência das desigualdades de poder e a capacidade de se organizar e se mobilizar) e a econômica (capacidade de gerar renda independente) (Stromquist, 2002, p. 232).

Nos últimos oito anos, a plataforma de registro das atividades do PET (SIGPET), criada pelo Ministério da Educação, regista a aprovação e participação de cinquenta petianos no PET Antropologia, dos quais trinta e duas são do gênero feminino, perfazendo sessenta e quatro por cento dos participantes. Tais números podem ser sugestivos, para além de sazonalidades (embora essa nunca seja fruto do acaso, mas de configurações sociais), do aumento da participação feminina nos espaços acadêmicos, estimulada pelas políticas patrocinadas pelos governos de esquerda nas últimas décadas no Brasil.

Acreditamos e defendemos que o PET-Antropologia foi e continua a ser um ambiente de empoderamento do feminino. Para além da possibilidade da formação intelectual, a qual possibilita às petianas se preparem para o ingresso numa pós-graduação e, posteriormente, na atividade acadêmica, ele fomenta um conjunto de experiências no qual essas mulheres, muitas vezes marcadas por uma cultura que as levam ao silenciamento, a um estilo de vida tímido, retraído e amedrontado, são instadas, no ambiente do PET, a falarem, a não terem medo, a se socializarem num ambiente onde aprendem a se colocar se confrontar com as várias formas de ler o social, se posicionando, defendendo o seu ponto de vista, enfim, se empoderando diante de si, dos outros e do mundo que as cerca.

Neste sentido, o PET-Antropologia tem ajudado na formação de um quadro de jovens antropólogas que, espalhadas por diferentes Universidades no Nordeste brasileiro e em outras regiões do Brasil, tem dado uma contribuição competente à formação e amadurecimento da Antropologia. 


\section{REFERÊNCIAS}

ALMEIDA, Heloisa Buarque de. Gênero. In: Blogs de Ciência da Universidade Estadual de Campinas: Mulheres na Filosofia. V.6, N³, 2020.

BADINTER, Elisabeth. Um Amor Conquistado. O Mito do Amor Materno. $3^{\text {a }}$ edição, Rio de Janeiro, Editora Nova Fronteira, 1985.

BIROLI, Flávia. Gênero e Política no noticiário das revistas semanais brasileiras: ausências e estereótipos. Cadernos Pagu, n 34, janeiro-junho de 2010.

CASTRO, Mary Garcia. Mulheres sindicalizadas: classe, gênero, raça e geração na produção de novos sujeitos políticos, um estudo de caso. In: HOLLANDA, Heloisa Buarque de. (org.) Pensamento Feminista Brasileiro: formação e contexto. Rio de Janeiro, Bazar do Tempo, 2019.

DAMATTA, Roberto. A Casa e a Rua. Espaço, cidadania, mulher e morte no Brasil. São Paulo, Brasiliense, 1985.

FECHINE, Joseana Macedo; LIMA, Elizabeth C. de Andrade \& ARAÚJO, Denise Lino de. A educação tutorial e as novas formas de ação e de atuação na prática pedagógica. In: PET Programa de Educação Tutorial: estratégia para o desenvolvimento da graduação. Brasília, Ministério da Educação, 2007.

KATO, Regina Aiko F. \& FAGGIAN, Lívia F. O enfoque problematizador no ensino tutorial: a descoberta pela atividade. In: PET Programa de Educação Tutorial: estratégia para o desenvolvimento da graduação. Brasília, Ministério da Educação, 2007.

MARTINS, Iguatemy Lucena. Educação tutorial no ensino presencial: uma análise sobre o PET. In: PET Programa de Educação Tutorial: estratégia para o desenvolvimento da graduação. Brasília, Ministério da Educação, 2007.

MEAD, Margaret. Sexo e Temperamento. São Paulo, Perspectiva, 1999.

SARDENBERG, Cecília M. B. Conceituando "Empoderamento" na Perspectiva Feminista. In: I Seminário Internacional: Trilhas de Empoderamento de Mulheres - Projeto TEMPO. NEIM/UFBA, Salvador, 2006.

SCOTT, Joan. "Gênero: uma categoria útil para análise histórica”. In: HOLLANDA, Heloisa B. (org.). Pensamento Feminista: conceitos fundamentais. Rio de Janeiro, Bazar do Tempo, 2019.

STROMQUIST, Nelly P. "Education as a means for empowering women”. In: PAPART, S. Rai \& K. Staudt (eds). Rethinking empowerment: gender and development in a global/local word. London, Routledge, pp.22-38.

TIBURI, Marcia. Feminismo em comum. Para todas, Todas e Todos. $7^{\text {a }}$ edição, Rio de Janeiro, Rosa Dos Tempos, 2018. 